\title{
PENGEMBANGAN ALAT PERAGA KIMIA SEDERHANA (ALGATOMIOKUL) PADA MATERI ATOM, ION DAN MOLEKUL UNTUK MENINGKATKAN AKTIVITAS BELAJAR SISWA
}

\author{
Peri Oktiarmi \\ SMAN 3 Kota Jambi, Provinsi Jambi \\ Email: peakeuy@gmail.com
}

\begin{abstract}
Abstrak
Penelitian ini memaparkan hasil kreativitas dan inovasi pengembangan alat perga pembelajaran pendidikan kimia sederhana (algatomiokul) pada materi atom, ion dan molekul untuk meningkatkan aktivitas belajar siswa. Pengujian alat peraga dilakukan melalui validasi oleh tiga orang ahli desain pembelajaran, produk /desain grafis dan substansi materi. Setelah perangkat pembelajaran divalidasi dan direvisi, dilakukan pengujian kepada guru kimia yang mengajar di sekolah serta uji coba di kelas secara kelompok kecil dan kelompok besar. Validasi dilakukan oleh dua orang validator, dimana bertujuan agar komentar yang diberikan semakin banyak sehingga media yang dihasilkan juga semakin menarik dan memiliki kualitas yang baik. Uji coba penelitian melibatkan dua puluh sembilan orang siswa yang dikelompokkan menjadi tiga kategori yaitu kemampuan yang sangat baik, sedang dan lemah. Pengelompokan betujuan agar peneliti bisa melihat pada kelompok mana media ini dapat diterapkan dengan baik.
\end{abstract}

Kata Kunci: alat peraga, atom, ion dan molekul, efektivitas

\section{Pendahuluan}

Materi pembelajaran kimia di SMA merupakan salah satu konsep ilmu kimia yang dipelajari di SMA adalah konsep tentang "Atom, Ion, dan Molekul". Konsep atom menurut Dalton, Thomson, Rutherford dan Bohr sangat abstrak dan teoritis, sehingga menimbulkan kebosanan pada siswa. Penggunaan media berupa alat peraga dalam menyampaikan konsep atom sangat diperlukan untuk membantu pemahaman siswa terhadap konsep atom tersebut. Ketika guru akan menjelaskan tentang konfigurasi elektron, siswa masih sering salah dalam menentukan konfigurasi elektron untuk unsur golongan A, khususnya unsur dengan nomor atom di atas 18. Kesalahan siswa dalam menentukan konfigurasi elektron ini akan berdampak pada kesalahan siswa dalam menentukan elektron valensi, serta menentukan perioda dan golongan dari suatu unsur, pembentukan anion, pembentukan kation, pembentukan senyawa ion, dan pembentukan molekul. Penjelasan pembentukan anion, pembentukan kation, dan pembentukan senyawa ion juga sangat abstrak. Guru jarang sekali menggunakan alat peraga untuk menyampaikan konsep ini, sehingga berpengaruh pada tingkat pemahaman dan aktivitas siswa. Demikian pula pada konsep pembentukan dan perbedaan molekul unsur dan molekul senyawa. Konsep ini juga abstrak.

Salah satu konsep ilmu kimia yang dipelajari di SMA adalah konsep tentang 
"atom, senyawa, ion, dan molekul". Konsep ini diberikan kepada siswa kelas $\mathrm{X}$ semester 1. Penggunaan alat peraga diharapkan dapat meningkatkan pemahaman siswa tentang bagaimana molekul unsur dan molekul senyawa terbentuk dan perbedaan keduanya. Selain itu, dengan alat peraga diharapkan guru dapat menyampaikan konsep ini dengan lebih menarik sehingga menciptakan persepsi siswa bahwa pelajaran kimia dapat dipelajari dengan cara yang menyenangkan dan tidak membosankan.

Sejauh ini pembelajaran kimia tentang molekul di SMA N 3 Kota Jambi dilakukan dengan metode konvensional atau ceramah dan diskusi informasi. Materi ini sebenarnya menuntut keterlibatan siswa lebih aktif. Bila ditilik dari materinya yang sarat dengan teori-teori dan konsep yang abstrak, dimana menuntut penalaran yang sangat tinggi. Keterlibatan siswa dalam proses belajar mengajar merupakan suatu hal yang sangat menentukan dalam pencapaian prestasi belajar, dan harus didukung oleh media pembelajaran dan metode atau model pembelajaran yang tepat oleh guru. Menurut Wager (2002) dalam Widodo, C.S., dkk. (2008), media ajar yang berbeda akan memberikan pengalaman yang berbeda bagi peserta didik.

Pada hakikatnya pembelajaran kimia bukan saja sekedar mengingat dan memahami fakta-fakta, tetapi juga mendorong siswa untuk dapat memecahkan masalah melalui nilai dan sikap ilmiah. Namun berdasarkan kenyataan, bahwa pendidikan kimia sebagai bagian integral dari kimia masih dianggap sebagai pelajaran yang sulit dan membosankan oleh sebagian besar siswa SMA termasuk di SMA Negeri 3 Kota Jambi. Secara umum permasalahan yang dihadapi pada proses pembelajaran kimia tidak jauh berbeda dengan ilmu lainnya. Namun demikian ilmu kimia yang mempelajari tentang fenomena alam yang tidak dapat dilihat menjadikan cara penyampaian pesan ilmu kimia tersebut menjadi tidak mudah.

Selain itu muncul anggapan bahwa pelajaran kimia merupakan pelajaran yang sulit dan membosankan. Hal ini disebabkan oleh beberapa faktor, diantaranya adalah sistem pembelajaran, media dan cara penyampaian yang dilakukan oleh guru monoton, membosankan, tidak melibatkan para siswanya dan didominasi oleh guru (Teacher Centre) yakni guru menjadi satu-satunya sumber pengetahuan. Guru masih banyak menerapkan metode ceramah sebagai sarana untuk mentransfer pengetahuan, sehingga siswa cepat bosan dan tidak tertarik dengan pembelajaran yang sedang berlangsung. Hal inilah yang akhirnya menyebabkan siswa kurang termotivasi dalam belajar kimia. Dengan demikian pemilihan media, metode dan pendekatan yang tepat diharapkan dapat membantu siswa dalam memahami konsep ilmu kimia.

Dengan demikian perlu dilakukan upaya untuk meningkatkan pemahaman siswa pada materi atom, ion dan molekul. Hal inilah yang kemudian menjadi dasar bagi penulis untuk mencoba membuat alat peraga alternatif sebagai media bantu bagi siswa dalam memahami konsep, atom, konfigurasi elektron, pembentukan kation, pembentukan anion, pembentukan senyawa ion, dan pembentukan molekul. Berdasarkan hal tersebut, penulis kemudian mencoba membuat alat peraga yang diharapkan dapat membantu siswa dalam mengatasi kesulitan-kesulitan pada pembelajaran konsep atom, ion dan molekul. Alat peraga tersebut dinamakan "Algatomiokul" (alat peraga atom, ion dan molekul). Salah satu konsep ilmu kimia yang dipelajari di SMA adalah konsep 
tentang "atom, seyawa, ion, dan molekul". Konsep ini diberikan kepada siswa kelas $\mathrm{X}$ semester 1, sehingga guru diharapkan dapat menyampaikan konsep ini semenarik mungkin untuk menciptakan persepsi kepada siswa bahwa pelajaran kimia juga dapat dipelajari dengan cara yang menyenangkan dan tidak membosankan.

Tujuan penelitian ini adalah mengembangkan alat peraga untuk membantu proses pembelajaran kimia yang menarik dan menyenangkan yang berdampak pada peningkatan motivasi, respons positif, dan hasil belajar siswa. Penelitian dilakukan untuk menguji efektivitas alat peraga model atom senyawa karbon yang digunakan dalam proses pembelajaran kimia pokok bahasan senyawa karbon, khususnya yang meliputi aktivitas belajar, respons, dan hasil belajar kimia siswa di SMAN 3 Kota Jambi. Selain itu, penelitian ini dimaksudkan untuk mengetahui metode yang dapat diterapkan pada pembelajaran kimia di kelas yang dapat mengintegrasikan nilainilai karakter bangsa ke dalam materi yang sedang diajarkan.

\section{Metode Penelitian}

Jenis penelitian yang akan dilakukan yaitu penelitian pengembangan (Research and Development).

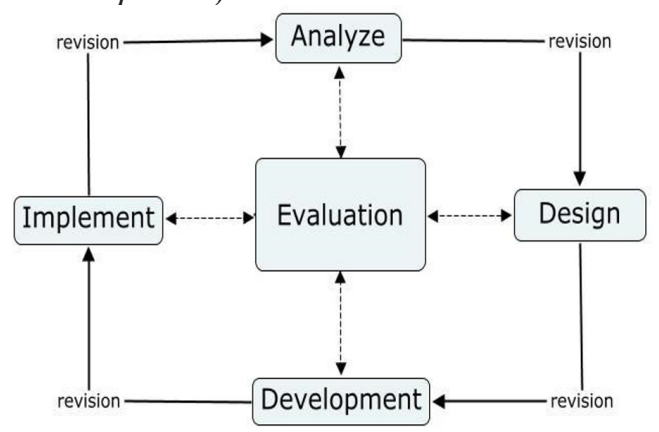

Gambar 1. Desain pengembangan (ADDIE, 2004)
Secara garis besar model penelitian pengembangan ini terdiri dari lima langkah yaitu: (1) analisis (analysis) (2) desain (design) (3) pengembangan (development) (4) implementasi (implementation) (5) evaluasi (evaluation). Penelitian ini mengembangkan perangkat pembelajaran berupa alat peraga yang berorientasi pada pengembangan dan peningkatan keterampilan proses sains siswa. Model ADDIE pada dasarnya adalah bahwa model ini generik yang sistematis. Dipilihnya model ADDIE dalam pengembangan ini, didasarkan pada beberapa alasan, yaitu: (1) model ini berupa model prosedural, yaitu model yang bersifat deskriptif, menunjukkan langkah-langkah yang jelas dan cermat untuk menghasilkan produk. (2) tahap-tahap pengembangan dalam model ini sama dengan standar tahap pengembangan, namun model ini dirancang khusus untuk pembelajaran berbasis alat peraga. Penelitian pengembangan ini dilakukan untuk memastikan: (1) peserta didik mencapai tujuan, (2) memungkinkan untuk evaluasi kebutuhan pembelajar, (3) desain dan pengembangan materi pelatihan, dan (4) evaluasi efektivitas pelatihan program menggunakan proses dengan spesifik dan hasil yang terukur.

\section{Hasil Penelitian dan Pembahasan}

Selama proses belajar mengajar berlangsung, teman sejawat melakukan pengamatan terhadap aktivitas siswa. Kemudian setelah proses belajar mengajar selesai dilaksanakan, dilakukan penyebaran angket dan post tes untuk mengetahui respons dan hasil belajar siswa sehingga dapat diambil kesimpulan tentang efektivitas atom, ion dan molekul. Untuk pembuatan algatomiokul digunakan alat dan bahan seperti: pisau cutter, gunting, cat, bola mainan anak-anak, kardus, karton padi, dan busa spoon. 
Proses pembuatan alat peraga adalah sebagai berikut:

\section{Model atom}

a. Ambil beberapa potong kapur tulis, lalu potong-potong sampai pada akhirnya didapat bagian dari kapur yang sangat kecil. Ini digunakan sebagai model atom menurut Jhon Dalton.

b. Ambil satu bola mainan anak-anak yang berdiameter $\pm 10 \mathrm{~cm}$ dan beberapa bola kecil yang berdiameter $\pm 1 \mathrm{~cm}$. Lalu tempelkan bola-bola kecil tersebut di sekeliling bola besar. Kemudian beri tanda - (negatif) pada bola-bola kecil dan tanda + (positif) pada bola besar. Ini digunakan sebagai model atom JJ. Thomson.

c. Buatlah setengah bola dari bola yang berdiameter $\pm 10 \mathrm{~cm}$. Buatlah permukaan bola tersebut dari karton padi dan berilah warna. Buatlah inti atom dan lintasan-lintasan elektron pada bagian tengah bola. Ini digunakan sebagai model atom Neils Bohr.

\section{Alat peraga konfigurasi elektron}

a. Buatlah bulatan-bulatan dari kardus sebanyak 7 buah yang ukurannya semakin lama semakin membesar. Lalu beri tanda huruf $\mathrm{K}$ pada bulatan yang paling kecil dan tanda Q pada bulatan yang paling besar. Kemudian ketujuh bulatan tersebut di lengketkan secara bersusun mulai dari yang paling kecil. Ini adalah sebagai lintasan-lintasan elektron.

b. Pada kulit $\mathrm{K}$ buatlah tiang-tiang kecil dari pipet sebanyak 2 buah, pada kulit L 8 buah, pada kulit M 18 buah, pada kulit N, O, P, dan Q sebanyak 32 buah yang akan digunakan sebagai tempat elektron-elektron. Berilah tiang-tiang tersebut nomor sesuai urutan. c. Selain nomor, setiap kulit juga di cat dengan warna hijau, kuning dan merah.

1. Pada kulit $\mathrm{K}$ dengan jumlah tiang sebanyak 2 buah diberi cat warna hijau.

2. Pada kulit L dengan jumlah tiang sebanya 8 diberi cat warna hijau.

3. Pada kulit M dengan jumlah tiang sebanyak 18 buah, untuk tiang dari nomor urut 1 sampai 8 diberi cat warna hijau, sedangkan pada tiang nomor urut 9 sampai 18 diberi cat warna kuning.

4. Pada kulit N, O, P, dan Q dengan jumlah tiang 32 buah, untuk tiang dari nomor urut 1 sampai 8 diberi cat warna hijau, tiang dari nomor urut 9 sampai 18 diberi cat warna kuning, dan pada tiang dari nomor urut 19 sampai 32 diberi cat warna merah.

5. Pada bagian tengah kulit $\mathrm{K}$ ditempel bola kecil sebagai simbol dari inti atom.

6. Elektron yang akan di konfigurasikan dapat digunakan buah alat hitung sempoa.

\section{Alat peraga pembentukan kation, anion, dan senyawa ion}

a. Ambil spoon gabus. Kemudian bentuk menjadi bulatan dengan ukuran yang disesuaikan. Apabila bulatan gubus tersebut dijadikan sebagai simbol kation, maka terdapat beberapa tonjolan yang jumlahnya disesuaikan dengan elektron valensinya, tonjolan ini sebagai simbol jemlah elektron yang akan dilepaskan untuk mencapai kestabilan. Apabila bulatan spoon gabus tersebut dijadikan sebagai simbol anion, maka terdapat beberapa lubang yang jumlahnya disesuaikan dengan berapa jumlah elektron yang akan diterima untuk mencapai 
kestabilan.

b. Agar lebih menarik, maka diberikan cat warna yang berbeda untuk membedakan kation dan anion. Untuk menjelaskan bagaimana senyawa ion terbentuk karena ada saling serah terima elektron, maka kedua alat peraga yang merupakan simbol kation dan anion seperti pada penjelasan di atas dapat digabungkan atau disatukan. Alat peraga molekul unsur dan molekul senyawa. (1) Ambil bola mainan anak-anak yang berdiameter kira-kira $5 \mathrm{~cm}$. Lalu catlah bola tersebut disesuaikan dengan warna unsur yang akan diperagakan, kemudian berilah simbol unsur tersebut. Kemudian berilah tangan dari setiap unsur yang jumlahnya sesuai dengan aturan yang berlaku. (2) Apabila ingin digunakan sebagai alat peraga, baik alat peraga molekul unsur maupun molekul senyawa, maka satukanlah dua atau lebih bola dengan menggunakan pipa karet sebagai rantainya yang disesuaikan dengan molekul apa yang akan dibuat.

\section{Aturan Penggunaan Alat Peraga}

\section{Alat Peraga Model atom}

Dalam penggunaan alat peraga model atom ini, siswa secara berkelompok melakukan pengamatan terhadap alat peraga yang ada, kemudian siswa diminta menuliskan hasil pengamatan mereka tentang apa pengertian atom menurut pengamatan mereka dari alat peraga yang ditampilkan. Dengan alat peraga ini, teori-teori atom yang sangat abstrak bagi siswa akan menjadi lebih konkret.

\section{Alat Peraga Konfigurasi elektron}

a. Pengisian elektron pada kulit-kulit dimulai dari kulit K, kemudian
L, M, dan seterusnya. Pengisian diprioritaskan terlebih dahulu pada orbit yang berwarna hijau. Jadi pada kulit $\mathrm{K}$ dan L, karena semua orbit berwarna hijau maka semua dapat diprioritaskan untuk di isi terlebih dahulu.

b. Pada kulit $M$, orbit yang berwarna hijau harus mendapat prioritas utama dalam pengisian elektron. Apabila semua orbit yang berwarna hijau telah terisi penuh, maka sisa elektron yang ada boleh diisikan pada orbit yang berwarna kuning dengan syarat bahwa orbit kuning tersebut harus terisi penuh. Apabila jumlah elektron sisa tidak mencukupi untuk mengisi elektron pada orbit yang berwarna kuning, maka sisa elektron tersebut diisikan pada orbit hijau di kulit berikutnya.

c. Pada kulit N, O, P dan Q, aturan pengisiannya adalah orbit hijau harus mendapat prioritas utama dalam pengisian elektron. Apabila semua orbit yang berwarna hijau telah terisi penuh, maka sisa elektron boleh diisikan pada orbit yang berwarna kuning dengan syarat orbit yang berwarna kuning harus terisi penuh. Apabila jumlah elektron sisa tidak mencukupi untuk mengisi penuh orbit kuning, maka sisa elektron tersebut hrus diisikan pada orbit yang berwarna hijau di kulit berikutnya. Namun apabila orbit yang berwana kuning bisa terisi penuh dan masih terdapat sisa elektron, maka dapat diisikan pada orbit yang berwarna hijau pada kulit berikutnya.

Dengan alat peraga ini, diharapkan pemahaman siswa tentang pola pengisian dan aturan dalam konfigurasi elektron akan terbentuk dengan sendirinya. 


\section{Alat peraga pembentukan kation, anion, dan senyawa ion}

Dalam menjelaskan bagaimana pembentukan kation dan anion, siswa diminta untuk mengamati spoon gabus yang telah disiapkan sebelumnya. Kemudian guru baru menjelaskan bagaimana kation dan anion dapat terbentuk. Selanjutnya siswa diminta untuk menggabungkan keduanya untuk menjelaskan bagaimana proses pembentukan senyawa ion dapat terjadi. Alat peraga ini juga dapat digunakan untuk menjelaskan bagaimana pembentukan molekul unsur dan molekul senyawa. Dengan alat peraga ini, materi yang selama ini sangat abstrak bagi siswa bisa menjadi lebih konkret.

\section{Alat Peraga Molekul Unsur dan Molekul Senyawa}

Bola-bola yang merupakan simbol dari unsur sesuai dengan warna dan lambangnya, dapat disatukan melalui tangan-tangan yang ada dengan bantuan selang karet. Apabila ingin menjelaskan tentang molekul unsur, maka dua atau lebih bola yang memiliki warna dan lambang yang sama dapat disatukan. Jika ingin menjelaskan tentang molekul senyawa, maka dua atau lebih bola yang memiliki warna dan lambang yang berbeda dapat disatukan sesuai dengan rumus senyawanya. Dengan alat peraga ini pemahaman siswa tentang perbedaan antara molekul unsur dan molekul senyawa akan terbentuk dengan sendirinya.

Adapun contoh alat peraga yang digunakan dalam pembelajaran adalah:
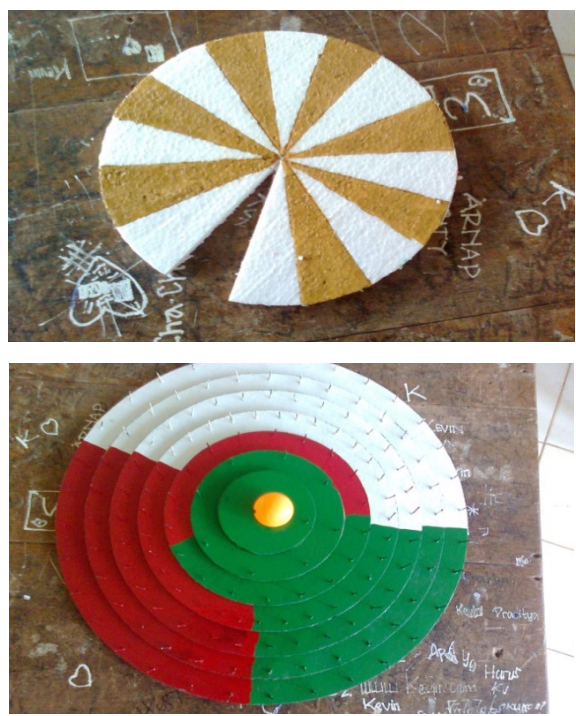

Penelitian ini juga mengumpulkan data terkait aktivitas siswa. Hasil pengamatan aktivitas siswa dalam pembelajaran adalah sebagai berikut:

Tabel 1. Rekapitulasi Hasil Pengamatan Aktivitas Siswa

\begin{tabular}{llccc}
\hline & Aspek Yang Diamati & \multicolumn{2}{c}{ Skor } & Rata \\
\cline { 3 - 5 } & & $\begin{array}{c}\text { Pert- } \\
\mathbf{1}\end{array}$ & $\begin{array}{c}\text { Pert- } \\
\mathbf{2}\end{array}$ & $\begin{array}{c}\text { Rata } \\
\text { Skor }\end{array}$ \\
\hline 1 & Siswa antusias dalam membentuk kelompok & 2 & 3 & 2,5 \\
\hline 2 & $\begin{array}{l}\text { Siswa mendengarkan penjelasan guru tentang materi yang diajar- } \\
\text { kan }\end{array}$ & 2 & 3 & 2,5 \\
\hline 3 & $\begin{array}{l}\text { Siswa mendengarkan penjelasan guru tentang tata cara dan atur- } \\
\text { an penggunaan alat peraga algatomiokul }\end{array}$ & 3 & 3 & 3 \\
\hline 4 & $\begin{array}{l}\text { Siswa antusias untuk mencoba menggunakan alat model atom } \\
\text { hidrokarbon algatomiokul }\end{array}$ & 3 & 3 & 3 \\
\hline 5 & Siswa antusias dalam mengajukan pertanyaan & 2 & 2 & 2 \\
\hline 6 & Siswa saling bekerjasama dan berinteraksi dalam kelompok & 2 & 3 & 2,5 \\
\hline 7 & Siswa antusias dalam diskusi membahas hasil kerja kelompok & 2 & 3 & 2,5 \\
\hline Jumlah Rata-Rata Skor & 16 & 20 & 18 \\
\hline Kriteria & Baik & & \\
\hline
\end{tabular}


Berdasarkan data pada Tabel 1 terlihat bahwa dari 7 aspek aktivitas siswa yang diamati selama proses belajar mengajar berlangsung, baik pada pertemuan 1 maupun pertemuan 2 , diperoleh data ratarata skor aktivitas siswa adalah 18 . Skor ini apabila dirujuk pada kisaran kategori data observasi, maka aktivitas siswa tersebut dapat dikategorikan baik.

\section{Angket Respons Siswa}

Berdasarkan hasil penyebaran angket yang dilakukan pada akhir pertemuan, diperoleh data respon siswa sebagai berikut:

Tabel 2. Hasil Angket Respon Siswa pada Pembelajaran

\begin{tabular}{|c|c|c|c|c|c|c|c|c|c|c|c|c|}
\hline \multirow{2}{*}{ No } & \multirow{2}{*}{ Nama } & \multicolumn{10}{|c|}{ Nomor dan Bobot Item Pertanyaan } & \multirow{2}{*}{$\begin{array}{c}\text { Jumlah } \\
\text { Skor }\end{array}$} \\
\hline & & 1 & 2 & 3 & 4 & 5 & 6 & 7 & 8 & 9 & 10 & \\
\hline 1 & DB & 4 & 4 & 4 & 3 & 4 & 3 & 4 & 3 & 4 & 3 & 36 \\
\hline 2 & DR & 4 & 4 & 3 & 4 & 4 & 4 & 4 & 4 & 4 & 3 & 38 \\
\hline 3 & EL & 4 & 4 & 4 & 4 & 4 & 4 & 4 & 4 & 4 & 4 & 40 \\
\hline 4 & ES & 3 & 3 & 4 & 4 & 3 & 3 & 3 & 3 & 3 & 4 & 33 \\
\hline 5 & FT & 3 & 3 & 4 & 3 & 3 & 4 & 3 & 4 & 4 & 3 & 34 \\
\hline 6 & GS & 4 & 4 & 4 & 4 & 4 & 3 & 4 & 4 & 4 & 4 & 39 \\
\hline 7 & HS & 4 & 4 & 4 & 4 & 3 & 4 & 3 & 4 & 3 & 3 & 36 \\
\hline 8 & $\mathrm{HN}$ & 4 & 4 & 4 & 3 & 4 & 3 & 3 & 4 & 4 & 4 & 37 \\
\hline 9 & $\mathrm{HV}$ & 4 & 4 & 4 & 4 & 4 & 4 & 4 & 3 & 3 & 3 & 37 \\
\hline 10 & IW & 4 & 4 & 4 & 4 & 4 & 4 & 3 & 4 & 4 & 4 & 39 \\
\hline 11 & $\mathrm{KR}$ & 4 & 4 & 4 & 4 & 4 & 4 & 4 & 4 & 4 & 3 & 39 \\
\hline 12 & LP & 4 & 4 & 3 & 4 & 4 & 4 & 3 & 4 & 4 & 4 & 38 \\
\hline 13 & ML & 4 & 4 & 3 & 4 & 4 & 4 & 4 & 4 & 4 & 4 & 39 \\
\hline 14 & YD & 4 & 3 & 4 & 4 & 4 & 4 & 3 & 3 & 4 & 4 & 37 \\
\hline 15 & OJ & 4 & 4 & 4 & 4 & 4 & 4 & 4 & 4 & 3 & 3 & 38 \\
\hline 16 & $\mathrm{RC}$ & 4 & 4 & 3 & 4 & 4 & 4 & 4 & 3 & 4 & 3 & 37 \\
\hline 17 & $\mathrm{RV}$ & 3 & 4 & 4 & 4 & 4 & 4 & 4 & 3 & 4 & 4 & 38 \\
\hline 18 & RK & 4 & 4 & 4 & 4 & 4 & 3 & 3 & 4 & 3 & 4 & 37 \\
\hline 19 & $\mathrm{RZ}$ & 4 & 4 & 4 & 4 & 4 & 3 & 3 & 4 & 4 & 4 & 38 \\
\hline 20 & RW & 4 & 4 & 4 & 4 & 4 & 4 & 4 & 4 & 3 & 4 & 39 \\
\hline 21 & $\mathrm{RN}$ & 4 & 4 & 3 & 4 & 4 & 4 & 4 & 4 & 4 & 3 & 38 \\
\hline 22 & $\mathrm{RB}$ & 4 & 4 & 4 & 4 & 4 & 4 & 3 & 4 & 4 & 4 & 39 \\
\hline 23 & $\mathrm{SD}$ & 3 & 4 & 4 & 3 & 4 & 4 & 3 & 4 & 3 & 4 & 36 \\
\hline 24 & $\mathrm{SN}$ & 4 & 4 & 4 & 4 & 4 & 4 & 4 & 4 & 4 & 3 & 39 \\
\hline 25 & $\mathrm{TN}$ & 4 & 4 & 3 & 4 & 3 & 3 & 4 & 4 & 4 & 3 & 36 \\
\hline 26 & WY & 4 & 4 & 4 & 3 & 4 & 3 & 4 & 4 & 4 & 4 & 38 \\
\hline
\end{tabular}




\begin{tabular}{|c|c|c|c|c|c|c|c|c|c|c|c|c|}
\hline \multirow{2}{*}{ No } & \multirow{2}{*}{ Nama } & \multicolumn{10}{|c|}{ Nomor dan Bobot Item Pertanyaan } & \multirow{2}{*}{$\begin{array}{c}\text { Jumlah } \\
\text { Skor }\end{array}$} \\
\hline & & 1 & 2 & 3 & 4 & 5 & 6 & 7 & 8 & 9 & 10 & \\
\hline 27 & WW & 4 & 4 & 4 & 4 & 4 & 4 & 4 & 4 & 3 & 3 & 38 \\
\hline \multicolumn{12}{|c|}{ Jumlah } & 1013 \\
\hline \multicolumn{12}{|c|}{ Persentase Respon Siswa (\%) } & $93,7 \%$ \\
\hline \multicolumn{12}{|c|}{ Kriteria Penilaian } & $\begin{array}{l}\text { Sangat } \\
\text { Positif }\end{array}$ \\
\hline
\end{tabular}

Jumlah responden : 27 Orang

\section{Nilai Post Test}

Adapun hasil pos test uji kelompok besar secara lengkap dapat dilihat pada tabel berikut ini:

Tabel 3. Hasil Post Test

\begin{tabular}{llll}
\hline No & $\begin{array}{c}\text { Nama } \\
\text { (Kode) }\end{array}$ & Skor & \multicolumn{1}{c}{ Kriteria } \\
\hline 1 & DB & 70 & Tuntas \\
\hline 2 & DR & 70 & Tuntas \\
\hline 3 & EL & 70 & Tuntas \\
\hline 4 & ES & 80 & Tuntas \\
\hline 5 & FT & 80 & Tuntas \\
\hline 6 & GS & 70 & Tuntas \\
\hline 7 & HS & 60 & Tidak Tuntas \\
\hline 8 & HN & 70 & Tuntas \\
\hline 9 & HV & 70 & Tuntas \\
\hline 10 & IW & 80 & Tuntas \\
\hline 11 & KR & 60 & Tidak Tuntas \\
\hline 12 & LP & 80 & Tuntas \\
\hline 13 & ML & 80 & Tuntas \\
\hline 14 & YD & 70 & Tuntas \\
\hline 15 & OJ & 80 & Tuntas \\
\hline 16 & RC & 80 & Tuntas \\
\hline 17 & RV & 80 & Tuntas \\
\hline 18 & RK & 80 & Tuntas \\
\hline 19 & RZ & 70 & Tuntas \\
\hline 20 & RW & 70 & Tuntas \\
\hline 21 & RN & 70 & Tuntas \\
\hline 22 & RB & 70 & Tuntas \\
\hline 23 & SD & 80 & Tuntas \\
\hline 24 & SN & 70 & Tuntas \\
\hline & & & \\
\hline 12 & & & \\
\hline 10 & & & \\
\hline
\end{tabular}

\begin{tabular}{llll}
\hline No & $\begin{array}{l}\text { Nama } \\
\text { (Kode) }\end{array}$ & Skor & \multicolumn{1}{c}{ Kriteria } \\
\hline 25 & TN & 60 & Tidak Tuntas \\
\hline 26 & WY & 70 & Tuntas \\
\hline 27 & WW & 80 & Tuntas \\
\hline Jumlah Skor Siswa & 1970 \\
\hline Daya Serap Siswa & $72,9 \%$ \\
\hline \multicolumn{2}{l}{ Nilai Rata-Rata Siswa } & 72,9 \\
\hline \multicolumn{2}{l}{ Ketuntasan Belajar } \\
Klasikal & 88,8 \\
\hline
\end{tabular}

Selain itu berdasarkan hasil penyebaran angket, terlihat bahwa persentase respon siswa adalah 93,7\% sehingga siswa dikatakan telah memberikan respon sangat positif (interval $75,6 \% \leq \mathrm{x} \leq 100 \%$ ) terhadap pembelajaran Kimia melalui penggunaan alat peraga algatomiokul. Hal ini dikarenakan siswa merasakan nuansa belajar sambil bermain sehingga proses pembelajaran yang berlangsung tidak membosankan dan menjenuhkan.

Secara teori siswa dikatakan tuntas belajar secara individual bila mendapat nilai 65 . Selain itu kriteria untuk tingkat kelas dianggap tuntas apabila $85 \%$ siswa di kelas memperoleh nilai 65 (Depdikbud dalam Triani, 2002:20). Berdasarkan data pada Tabel 9 di atas, terlihat bahwa jumlah siswa yang mengalami ketuntasan belajar yaitu 24 orang $(88,8 \%)$.

Berdasarkan hasil di atas, maka dapat dikatakan bahwa penggunaan alat peraga algatomiokul pada pembelajaran kimia 
pokok bahasan atom, ion dan molekul sangat efektif. Selain itu, penggunaan model atom algatomiokul banyak memberikan manfaat bagi siswa, di antaranya sebagai berikut:

1. Membuat siswa lebih termotivasi dan aktif, dinamis serta suasana belajar berlangsung dalam suasana yang menyenangkan.

2. Siswa dapat memperoleh gambaran konkret mengenai konfigurasi elektron, jenis-jenis atom, molekul dengan melihat dan memegang langsung alat peraganya, sehingga secara psikologis ini akan berpengaruh positif bagi siswa, dimana akan lebih mudah bagi siswa dalam menentukan teoriteori atom, jumlah kulit berdasarkan konfigurasi elektron sehingga (siswa tidak sekedar membayangkan).

Hasil penyebaran angket menunjukkan bahwa persentase respons siswa adalah 93,7\% sehingga siswa dikatakan telah memberikan respons sangat positif(interval $75,6 \% \leq x \leq 100 \%$ ) terhadap pembelajaran Kimia melalui penggunaan alat peraga algatomiokul. Hal ini dikarenakan siswa merasakan nuansa belajar sambil bermain sehingga proses pembelajaran yang berlangsung tidak membosankan dan menjenuhkan.

\section{Kesimpulan}

1. Penggunaan alat peraga ALGATOMIUKUL untuk pembelajaran kimia pokok bahasan aton ion dan molekul di SMA Negeri 3 Kota jambi tahun Pelajaran 2016/2017 sangat efektif. Hal ini dapat dilihat dari data aktivitas, respons dan hasil belajar siswa

2. Efektivitas penggunaan alat peraga hasil lembar aktivitas siswa dapat disimpulkan aktivitas siswa lebih meningkat dalam proses pembelajaran. Dimana dalam proses pembelajaran siswa aktif bertanya, menyampaikan ide/pendapat maupun dalam menyelesaikan tugas dengan tepat waktu.

3. Dari hasil test belajar, siswa mampu memenuhi kriteria ketuntasan minimal yang ditetapkan yaitu 75 . Dengan ratarata nilai hasil belajar yaitu 87,14 . Hal ini dapat dilihat dari respon siswa pada uji coba kelompok kecil dan kelompok besar dimana diperoleh kesimpulan media pembelajaran yang peneliti kembangkan dapat dikategorikan baik/menarik didalam penerapan pembelajaran kimia. Dengan demikian dari hasil lembar aktivitas siswa, hasil belajar siswa dapat disimpulkan alat peraga ALGATOMIUKUL dapat meningkatkan efektivitas siswa dalam pembelajaran kimia.

\section{Daftar Rujukan}

Arikunto, S. (2002). Dasar-Dasar Evaluasi Pendidikan. Jakarta Bumi Aksara.

Dimyati. 2004. Belajar dan Pembelajaran. Jakarta: Depdikbud.

Djamarah, S.B. (2008). Prestasi Belajar dan Kompetensi Guru. Surabaya: Usaha Nasional.

Hamalik, Oemar. (1999). Psikologi Belajar dan Mengajar. Bandung. Sinar Baru

Mustapa, Ali. (2011). "Pengaruh Penggunaan Multimedia Interaktif Terhadap Peningkatan Motivasi Siswa dalam Pembelajaran Bahasa Arab Kelas V MIN Malang 2". Tesis. PGMI: Universitas Islam Negeri Maulana Malik Ibrahim Malang.

Satri, Jaka. (2004). Upaya Meningkatkan Motivasi Dan Prestasi Belajar Kimia Siswa Pada Pokok Bahasan Materi Dan Perubahannya Melalui Penggunaan Perangkat Kit Praktikum Di Kelas I.E SMA Negeri 
3 Kota Bengkulu. Skripsi. Universitas Bengkulu.

Setiawan, Deni. (2008). Model Atom

Dari Mainan Anak-Anak Untuk

Pembelajaran Kimia. Makalah.

Bandung.

Setyowati. (2006). Pengaruh Motivasi

Belajar Terhadap Hasil Belajar

Siswa Kelas VII SMPN 13 Semarang.

Skripsi. Universitas Negeri Semarang

Suryatin, Budi. (2008). Kimia XI

Untuk SMA. Jakarta. PT. Gramedia

Widiasarana Indonesia.

Sutrisno, Sandra Pratama. (2011).

"Pengertian Respon". Disajikan di http://pratamasandra.wordpress. com/2011/05/11/pengertian-respon/ diunduh tanggal 5 Juni 2016.

Sudjana, N. (1995). Penilaian Hasil Proses Belajar Mengajar. Bandung: Remaja Rosda 